\title{
COMMENTS
}

\section{"Interested Adults" with Conflicts of Interest at Juvenile Interrogations: Applying the Close Relationship Standard of Emotional Distress}

\author{
Andy Clark $\dagger$
}

The procedural protections of the Bill of Rights apply to juveniles,' but not in precisely the same way as they apply to adults. One way juvenile protections differ is in the factors courts consider in determining the validity of a juvenile's waiver of the privilege against self-incrimination or of the right to counsel. The presence of an "interested adult," ${ }^{2}$ which usually is irrelevant to the validity of an adult's waiver, is an important factor in a court's determination of whether a juvenile's waiver is knowing, voluntary, and intelligent, and thus valid. The United States Constitution requires that courts consider the presence of an interested adult as part of an evaluation of the totality of the circumstances surrounding a juvenile's waiver. Some states go fur-

$\dagger \quad$ B.A. 1998, Rice University; J.D. Candidate 2001, The University of Chicago.

1 See In re Gault, 387 US 1, 12-13 (1967) (observing that "neither the Fourteenth Amendment nor the Bill of Rights is for adults alone").

2 The phrase "interested adult" has legal meaning which may vary by jurisdiction. This Comment applies the term to any adult who is not affiliated with the police or prosecution, who is present with a juvenile during a custodial interrogation of the juvenile, and who, at least ostensibly, intends to improve the general welfare of the juvenile. See, for example, In re E.T.C., $131 \mathrm{Vt}$ $375,449 \mathrm{~A} 2 \mathrm{~d} 937,940$ (1982) (ruling that the "adult must be one who is not only genuinely interested in the welfare of the juvenile, but completely independent from and disassociated with the prosecution, e.g., a parent, legal guardian, or attorney representing the juvenile"). A parent of the juvenile is the most typical interested adult, but as this Comment will use the term, it does not imply any particular relationship between the juvenile and the adult. This definition would include a lawyer for the juvenile.

3 A possible exception is waiver by a mentally deficient adult. See, for example, Henry $v$ Dees, 658 F2d 406, 411 (5th Cir 1981) (noting that "the presence of counsel should be assured absent an unmistakable, knowing waiver of that assistance" in a case involving a mentally retarded adult). The solution proposed by this Comment also applies to that situation.

4 These are the requirements of the Fifth Amendment. See Miranda v Arizona, 384 US 436, 444 (1966) (holding that the Fifth Amendment requires that waivers be voluntary, knowing, and intelligent). 
ther and require the presence of an interested adult to make admissible any statements made by a juvenile under interrogation.

A juvenile can contest the admission into evidence of statements she made under interrogation by challenging the competency of the interested adult who was present when she allegedly waived her privilege against self-incrimination and right to counsel. One ground on which to challenge an interested adult's competency is the existence of a conflict of interest between the juvenile and the adult. Courts sometimes have found waivers invalid on the basis of such a conflict of interest, but they have reached no consensus on when a conflict of interest exists between a juvenile and an adult in the custodial interrogation setting.

This Comment argues that the "close relationship" test developed in negligent infliction of emotional distress tort cases is an appropriate way to uncover many of these conflicts of interest. Plaintiffs in negligent infliction of emotional distress cases are often witnesses to a severe physical injury caused by a defendant's negligence. In most jurisdictions courts require such plaintiffs to show a close relationship to the victim of the physical injury in order to recover for emotional injury suffered as a bystander. Close relationships are typically limited to immediate family or similarly intimate relationships.

This Comment argues that a court should find an interested adult incompetent if the adult has a "close relationship," as that phrase has been defined in tort cases, ${ }^{6}$ with any victim of the crime of which the juvenile is accused, or with any other suspect in the crime. In jurisdictions where emotional distress law is underdeveloped, this Comment suggests as an alternative that a "close relationship" for the purposes of determining a conflict of interest should be defined as an immediate family relationship. This approach provides the police a clear rule to apply in determining whom to have present at a juvenile's interrogation, fosters consistency between areas of the law, helps to avoid coerced confessions by juveniles, and ensures that coerced confessions are inadmissible in court.

In Part I, the Comment describes the development and application of constitutional and statutory protections of the privilege against self-incrimination and the right to counsel, as applied to juveniles. Part

5 See Part I.C.2.

6 See, for example, Dunphy v Gregor, 136 NJ 99, 642 A2d 372, 380 (1994) (finding an "intimate familial relationship" sufficient to afford protection of bystander liability for a negligent infliction of emotional distress tort).

7 Courts very rarely, if ever, hold that an immediate family relationship does not qualify as a close relationship. Courts have included in the category of immediate family relationships, at a minimum, relationships between an individual and her parents, spouse, children, and siblings. See Part II.B. 
I then discusses the role of interested adults in juvenile waivers of rights, and introduces the problem of conflicts of interest between adults and juveniles and the use of such conflicts as grounds for challenging the competency of an interested adult. In Part II, the Comment defines the elements of a claim for negligent infliction of emotional distress, and describes the tests used by different jurisdictions to limit the scope of emotional distress damages. Part II then discusses the role of close relationships in determining reasonable foreseeability in negligent infliction of emotional distress cases, and examines particular relationships that have or have not been defined as close. In Part III, the Comment takes the close relationship standard described in Part II and applies it to conflicts of interest between juveniles and interested adults as described in Part I. Part III then discusses problems with this approach and alternative solutions, and illustrates the proposal's applications.

\section{JuVenile Waiver of the Privilege Against Self- INCRIMINATION AND THE RIGHT TO COUNSEL}

This Part first describes the history of the application to juveniles of the privilege against self-incrimination and the right to counsel and then surveys state approaches to juvenile waivers of rights. This Part concludes by introducing the problem of conflicts of interest between juveniles and interested adults.

\section{A. Constitutional Protections and Their Application by Federal Courts}

The federal Constitution requires that juvenile waivers of the privilege against self-incrimination and the right to counsel must be evaluated, at a minimum, by the totality of the circumstances surrounding the waiver. Part I.A.1 describes the development of this standard. Part I.A.2 examines its application by federal courts.

1. Development of the "totality of the circumstances" test for juvenile waivers.

Miranda $v$ Arizona ${ }^{8}$ remains the centerpiece of the Supreme Court's jurisprudence on custodial interrogation and the privilege against self-incrimination. ${ }^{9}$ Miranda held that the prosecution may not use in its case-in-chief statements obtained in a custodial interrogation

9 The Supreme Court recently affirmed the importance of the prophylactic measures outlined in Miranda. See Dickerson v United States, 530 US 428 (2000) (holding that Miranda warnings are constitutionally based and therefore cannot be abrogated by an act of Congress). 
unless it demonstrates the use of procedural safeguards by the police that are sufficient to secure the privilege against self-incrimination. ${ }^{10}$ In the absence of other fully effective safeguards, the Court requires the police to warn a suspect that he has a right to remain silent, that any statement he makes may be used as evidence against him, and that he has a right to the presence of an attorney, either retained or appointed." An accused may waive these rights, but only if the waiver is made "voluntarily, knowingly and intelligently." If the accused indicates in any manner that he wishes to consult an attorney, or that he does not wish to be interrogated, then the police must cease questioning.

In re Gault, ${ }^{14}$ decided only a year after Miranda, held that Miranda's requirements of warnings and of specific waivers also apply to juveniles. ${ }^{15}$ The case involved a fifteen-year-old boy committed to six years in a state juvenile detention facility for making obscene phone calls. ${ }^{16}$ The Supreme Court held that the Due Process Clause applies to juvenile proceedings, ${ }^{17}$ and reversed the juvenile's commitment on the basis of numerous procedural defects. ${ }^{18}$ In holding that the waiver provisions of Miranda apply to juveniles, the Court noted,

We appreciate that special problems may arise with respect to waiver of the privilege [against self-incrimination] by or on behalf of children, and that there may well be some differences in technique-but not in principle-depending upon the age of the child and the presence and competence of parents.

The Court's mention of "the presence and competence of parents" recalls two earlier cases that had reversed convictions of juveniles because of Due Process Clause violations, Haley $v$ Ohio $^{20}$ and Gallegos $v$ Colorado. ${ }^{21}$ In Haley, the Court ruled that a five-hour interrogation of a fifteen-year-old boy, without a parent or counsel present

$10 \quad 384$ US at 444.

11 Id.

12 Id.

13 Id at 444-45.

14387 US 1 (1967).

15 Id at 55 ("We conclude that the constitutional privilege against self-incrimination is applicable in the case of juveniles as it is with respect to adults.").

16 Id at 7.

17 Id at 13-14 ("As to [juvenile delinquency] proceedings, there appears to be little current dissent from the proposition that the Due Process Clause has a role to play. The problem is to ascertain the precise impact of the due process requirement upon such proceedings.").

18 The defects included failure to warn Gault of his right to remain silent, obtaining Gault's confession outside the presence of his parents and counsel, and failure to allow him to confront witnesses against him. Id at 56.

19 Id at 55.

20332 US $596(1948)$.

21370 US 49 (1962). 
and without advising him of his right to counsel, violated due process. ${ }^{22}$ The Court did not specifically require the presence of an interested adult to make a juvenile waiver valid, ${ }^{23}$ but the opinion repeatedly and eloquently suggested the importance of an adult's presence:

[A juvenile] needs counsel and support .... He needs someone on whom to lean lest the overpowering presence of the law, as he knows it, crush him. No friend stood at [the accused's] side.... No lawyer stood guard .... No counsel or friend was called. ${ }^{24}$

Gallegos, citing Haley, held that the five day detention of a fourteen-year-old boy, absent the presence of his parents, an attorney, or any adult friend, violated the Due Process Clause. ${ }^{25}$ As in Haley, the Court did not absolutely require the presence of a friendly adult for any waiver of a juvenile's privilege against self-incrimination, but it considered the absence of an interested adult an important factor in determining his confession to be invalid. ${ }^{26}$

The Supreme Court has never required per se the presence of an interested adult, and it made clear, in the 1979 case of Fare $v$ Michael $C_{.}{ }^{27}$ that juvenile waivers of Fifth Amendment rights should be judged by the "totality of the circumstances." In Fare, the Court reversed the decision of the California Supreme Court excluding the sixteen-yearold defendant's confession, which had been obtained without the presence of an interested adult or attorney and after the defendant

22332 US at 598-601. The opinion indicates that due process challenges to convictions of juveniles might be subject to a different standard than challenges to adult convictions. "[W]hen, as here, a mere child - an easy victim of the law - is before us, special care in scrutinizing the record must be used." Id at 599. But apparently the Court did not base its holding solely on the fact that the accused was a juvenile: "What transpired would make us pause for careful inquiry if a mature man were involved." Id.

23 The Court listed several factors, including lack of friendly adult presence, that made the confession inadmissible:

The age of petitioner, the hours when he was grilled, the duration of his quizzing, the fact that he had no friend or counsel to advise him, the callous attitude of the police towards his rights combine to convince us that this was a confession wrung from a child by means which the law should not sanction.

Id at $600-01$.

24 Id at 600 . Neither this opinion nor Gallegos relies specifically on a juvenile right to counsel or requires police to notify juveniles of such a right. Gault was the first case in the Supreme Court to do so. See text accompanying notes 14-19.

25370 US at 55 ("A lawyer or an adult relative or friend could have given the petitioner the protection which his own immaturity could not.").

26 Like Haley, Gallegos lists several factors that led to the Court's decision: "The youth of the petitioner, the long detention, the failure to send for his parents, the failure immediately to bring him before the judge of the Juvenile Court, the failure to see to it that he had the advice of a lawyer or a friend." Id.

$27 \quad 442$ US 707 (1979).

28 Id at 728 . 
had requested to see his probation officer. ${ }^{29}$ The central issue in the case was whether the juvenile's request to see his probation officer was equivalent per se to a request to see an attorney for purposes of Miranda; the Court held that it was not. ${ }^{30}$ Rather, the Court ruled that the admissibility of statements obtained after such a request was "to be resolved on the totality of the circumstances surrounding the interrogation." According to Fare, the totality approach "includes evaluation of the juvenile's age, experience, education, background, and intelligence, and into whether he has the capacity to understand the warnings given him, the nature of his Fifth Amendment rights, and the consequences of waiving those rights."

Fare does explicitly what Haley and Gallegos had done implicitly: It treats a juvenile due process challenge as primarily a factual inquiry, to be determined by the circumstances of the case rather than by application of specific rules. ${ }^{33}$ Although in a sense Fare is contrary to the trend seen in Miranda and Gault of structured, rules-based approaches to due process analysis, nothing in Fare conflicts with either of those cases.

\section{Application of the "totality of the circumstances" test by} federal courts.

The "totality of the circumstances" approach is the constitutional standard by which the presence or competence of an interested adult is judged. There is no per se rule at the federal level, either in the Constitution or supplied by statute, requiring the presence of a competent adult to validate a juvenile waiver of the privilege against selfincrimination. As the Eighth Circuit stated in United States $v$ White Bear," "It is apparent ... that the Court does not hold the presence of parents or counsel necessary to obtain a valid confession or that juveniles are incapable of waiving the right to remain silent., ${ }^{35}$ To similar effect is the Fourth Circuit opinion in United States $v$ Miller, ${ }^{36}$ which

29 Id at $727-28$.

30 Id at 724.

31 Id at 728. The dissent, citing Haley, Gallegos, and Gault, argued that "Miranda requires that interrogation cease whenever a juvenile requests an adult who is obligated to represent his interests." Id at 729 (Marshall dissenting).

32 Id at 725. The list does not mention friendly adult presence or competence, as Haley, Gallegos, and Gault had, but presumably the Court would include presence or competence of a friendly adult in consideration; it states, "The totality approach permits - indeed, it mandates inquiry into all the circumstances surrounding the interrogation." Id.

33 Although the Gallegos opinion uses the phrase "totality of circumstances," it seems unenthusiastic about doing so: "There is no guide to the decision of cases such as this, except the totality of circumstances." Gallegos, 370 US at 55.

34668 F2d 409 (8th Cir 1982).

35 Id at 412.

36453 F2d 634 (4th Cir 1972). 
found, in a case where the accused was questioned without any interested adult present, that the juvenile's age alone was not a decisive factor and that a fourteen-year-old could in some cases intelligently waive his rights.

Two federal cases illustrate the application of the federal totality of the circumstances test. The first is Vance $v$ Bordenkircher, ${ }^{38}$ a typical case arising under federal law that considers the necessity of the presence of an interested adult. In Vance, a fifteen-year-old boy with a mental deficiency confessed to murder during a custodial interrogation, outside the presence of any adult other than the police. ${ }^{39}$ Vance subsequently was convicted of first-degree murder. ${ }^{40}$ The Fourth $\mathrm{Cir}$ cuit examined the totality of the circumstances and affirmed the district court's denial of relief on a habeas corpus petition. ${ }^{41}$ The court did not treat the absence of an interested adult as a determinative factor, especially in light of the fact that the boy's "mother was made aware of the arrest and she voluntarily chose not to accompany him to jail."," Because Vance had been informed of his rights, and the police had not restricted Vance's access to his mother or any other interested adult, the court considered the waiver valid. ${ }^{43}$

The second case is United States $v$ Homer B., ${ }^{44}$ a case that arose under federal law concerning the competence of an interested adult. In that case the two juvenile defendants had given statements implicating themselves in the rape of a fourteen-year-old girl. ${ }^{45}$ The Ninth Circuit upheld the district court's admission of the statements. ${ }^{45}$ One of the defendants, Ernest J., was accompanied only by his older sister at the time he waived his privilege against self-incrimination. ${ }^{47}$ The court gave some consideration to the fact that the adult present was the defendant's sister, rather than a parent, ${ }^{48}$ but, in the end, did not find this fact to weigh against admissibility. ${ }^{49}$

37 Id at 636 ("We are not prepared to hold that a boy of fourteen is never capable of making an intelligent waiver of his rights... [N]o court has held that age alone is determinative.").

38692 F2d 978 (4th Cir 1982).

39 Id at 979 .

40 Id at 980 .

41 Id at 981 ("[We] do not believe that it may be said that Vance's confession was involuntary.").

42 Id.

43 Id. The court found that everything about the interrogation except Vance's diminished mental capacity tended to show voluntariness in his confession. Id.

441990 WL 79705 (9th Cir) (unpublished opinion).

45 Id at *1.

46 Id at *4.

47 Id at *2.

48 See id (noting that the interrogator questioned the sister about the location of their parents).

49 See id at $* 4$ (upholding admissibility of confession). 


\section{B. State Approaches}

Most states apply the constitutional totality of the circumstances test to juvenile waivers, but some states have added per se rules that require the presence of an interested adult to validate a juvenile's waiver. Part I.B.1 examines the states that use the totality of the circumstances standard and shows some refinements they have made to it. Part I.B.2 discusses the states that use per se rules and describes their operation.

\section{Totality of the circumstances test.}

Although states may not establish criminal procedures that are less protective than those guaranteed by the federal Constitution, states are free to adopt more protective measures governing their own criminal systems' treatment of juveniles in custodial interrogations. ${ }^{50}$ However, most states decline to go beyond the protections guaranteed by the Constitution: they too apply a totality of the circumstances test to juvenile waivers of the privilege against self-incrimination. ${ }^{51}$

so See, for example, Smith v Robbins, 528 US 259, 273 (2000) (observing in a criminal procedure case that "the states [have] wide discretion, subject to the minimum requirements of the Fourteenth Amendment, to experiment with solutions to difficult problems of policy"); Spencer $v$ Texas, 385 US 554, 569 (1967) (Stewart concurring) (noting, in criminal procedure case, that "[t]he question is whether [Texas's] procedures fall below the minimum level the Fourteenth Amendment will tolerate").

51 See Trey Meyer, Comment, Testing the Validity of Confessions and Waivers of the SelfIncrimination Privilege in the Juvenile Courts, 47 Kan L Rev 1035, 1051 (1999) ("[A] vast majority of the states [have] recognized that the totality of the circumstances test is appropriate for assessing the validity of waivers of the privilege against self-incrimination by juveniles.").

The following states utilize the totality of the circumstances rule: Alabama, Flowers v State, 586 \$2d 978, 983 (Ala Crim App 1991); Alaska, Quick v State, 599 P2d 712, 719-20 (Alaska 1979); Arizona, State v Rodriquez, 113 Ariz 409, 555 P2d 655, 658 (Ariz 1976); Arkansas, Miller v State, 338 Ark 445, 994 SW2d 476, 479-81 (1999); California, People v Lara, 67 Cal 2d 365, 432 P2d 202, 215 (1967); Delaware, Haug v State, 406 A2d 38, 43 (Del 1979); Florida, Ramirez v State, 739 S2d 568, 578 (Fla 1999); Georgia, Riley v State, 237 Ga 124, 226 SE2d 922, 926 (1976); Hawaii, In re Doe, 90 Hawaii 246, 978 P2d 684, 686 (1999); Idaho, State v Doe, 131 Idaho 709, 963 P2d 392, 395 (Idaho App 1998); Illinois, In re G.O., 191 Ill 2d 37, 727 NE2d 1003, 1012 (2000); Louisiana, State v Fernandez, 712 S2d 485, 490 (La 1998); Maine, State v Nicholas S., 444 A2d 373, 377 (Maine 1982); Maryland, McIntyre v State, 309 Md 607, 526 A2d 30, 34 (1987); Michigan, People v Abraham, 234 Mich App 640, 599 NW2d 736, 739-40 (1999); Minnesota, State v Scott, 584 NW2d 412, 417 (Minn 1998); Mississippi, Dancer v State, 721 S2d 583, 587 (Miss 1998); Missouri, State v Pierce, 749 SW2d 397, 402 (Mo 1988); Nebraska, State v J.G., 231 Neb 530, 437 NW2d 153, 154 (1989); Nevada, Elvik v State, 114 Nev 883, 965 P2d 281, 286 (1998); New Hampshire, In re Wesley B., 764 A2d 888, 891 (NH 2000); New Jersey, State v Presha, 163 NJ 304, 748 A2d 1108, 1110 (2000); New Mexico, State v Lasner, 129 NM 806, 14 P3d 1282, 1285 (2000); New York, Matter of Stanley C., 116 AD2d 209, 500 NYS2d 445, 448 (1986); North Dakota, Shirey v B.S., 496 NW2d 31, 34 (ND 1993); Ohio, In re Watson, 47 Ohio St 3d 86, 548 NE2d 210, 214 (1989); Oregon, Juvenile Dept of Lincoln County v Cook, 138 Or App 401, 909 P2d 202, 204 (1996); Pennsylvania, Commonwealth $v$ Williams, 504 Pa 511, 475 A2d 1283, 1288 (1984); Rhode Island, In re Kean, 520 A2d 1271, 1276 (RI 1987); South Dakota, State v Janis, 356 NW2d 916, 918 (SD 1984); Tennessee, State $v$ Callahan, 979 SW2d 577, 582-83 (Tenn 1998); Texas, In Interest of R.D., 627 SW2d 803,807 
State courts and legislatures sometimes refine the totality of the circumstances standard by listing relevant factors to be considered. Indiana, for example, requires by statute that "all the circumstances of the waiver" be considered in deciding whether it was voluntary, and provides a nonexclusive list of six factors to be included in consideration. The most extensive list of factors appears to be found in the New Hampshire case of State $v$ Benoit, ${ }^{53}$ and includes:

(1) the chronological age of the juvenile; (2) the apparent mental age of the juvenile; (3) the educational level of the juvenile; (4) the juvenile's physical condition; (5) the juvenile's previous dealings with the police or court appearances; (6) the extent of the explanation of rights; (7) the language of the warnings given; (8) the methods of interrogation; (9) the length of interrogation; (10) the length of time the juvenile was in custody; (11) whether the juvenile was held incommunicado; (12) whether the juvenile was afforded the opportunity to consult with an adult; (13) the juvenile's understanding of the offense charged; (14) whether the juvenile was warned of possible transfer to adult court; and (15) whether the juvenile later repudiated the statement.

However, even this list is not comprehensive.

One rationale for the totality of the circumstances test is that juvenile courts are in the best position to judge the voluntariness of a confession. ${ }^{\text {ss }}$ Other arguments in favor of the totality of the circumstances approach and against the per se approach are that requiring

(Tex App 1982); Utah, State v Dutchie, 969 P2d 422, 427 (Utah 1998); Vermont, State v Mears, 170 Vt 336, 749 A2d 600, 604 (2000); Virginia, Harris v Commonwealth, 217 Va 715, 232 SE2d 751, 755 (1977); Washington, State v Loukaitis, 1999 Wash App LEXIS 1955, *20; Wisconsin, State v Jones, 192 Wis 2d 78, 532 NW2d 79, 88 (1995); and Wyoming, Rubio v State, 939 P2d 238, 242 (Wyo 1997). There appear to be no reported decisions in Kentucky or South Carolina considering the issue.

52 Ind Code Ann $\S 31-32-5-4$ (West 1999). The factors listed are:

(1) The child's physical, mental, and emotional maturity.

(2) Whether the child or the child's parent, guardian, custodian, or attorney understood the consequences of the child's statements.

(3) Whether the child and the child's parent, guardian, or custodian had been informed of the delinquent act with which the child was charged or of which the child was suspected.

(4) The length of time the child was held in custody before consulting with the child's parent, guardian, or custodian.

(5) Whether there was any coercion, force, or inducement.

(6) Whether the child and the child's parent, guardian, or custodian had been advised of the child's right to remain silent and to the appointment of counsel.

Id.

$53126 \mathrm{NH} 6,490$ A2d 295 (1985).

54 Id at 302.

55 See Fare, 442 US at 725 (noting that juvenile courts have "special expertise in this area"). 
an interested adult per se is overly protective, that it excludes from evidence statements that are in fact knowingly and voluntarily given, and that it unnecessarily restricts the activity of the police. ${ }^{56}$ Since the nature of the totality of the circumstances approach is that the weight allocated to various criteria depends on the circumstances of a particular juvenile, the application of the test will vary greatly from case to case. Some commentators have argued against the totality of the circumstances approach for this reason, saying that it is speculative and gives the police no way to know whether a juvenile's confession will be admissible. ${ }^{58}$ One commentator has additionally argued that courts have been too conservative in their application of the totality test and have found waivers voluntary despite the presence of coercive factors. ${ }^{59}$

\section{Per se rules.}

Some states, in addition to the federal constitutional requirements, have adopted per se rules. ${ }^{60}$ These rules typically require the presence of a parent or a similarly situated adult to validate any juvenile waiver of the privilege against self-incrimination. A waiver by a juvenile under a certain age is not valid if an interested adult is not present, no matter how strongly other factors may suggest that the

56 See Kean, 520 A2d at 1275.

57 See Lawrence Schlam, Police Interrogation of Children and State Constitutions: Why Not Videotape the MTV Generation?, 26 U Toledo L Rev 901, 913 (1995) (observing that totality test lacks "any criteria indicating the weight a court should give to the various circumstances surrounding a custodial interrogation").

58 See id at 913-14 (arguing that "it is practically impossible for the police to determine whether a juvenile's confession will be admissible" and observing that some courts have rejected the totality of the circumstances test precisely because "the lack of specific standards leads to speculation on the part of the authorities interrogating juveniles").

59 Id at 914.

60 The following states have adopted per se rules: Colorado, Colo Rev Stat Ann \& 19-2-511 (West 1998 \& Supp 2000) (making inadmissible statements made by juvenile under eighteen without presence of interested adult, except in unusual circumstances); Connecticut, Conn Gen Stat Ann $§ 46 \mathrm{~b}-137$ (West 1998 \& Supp 2000) (requiring parental presence for statements made by child to be admissible); Indiana, Ind Code Ann $\$ 31-32-5-1$ (West 1998) (requiring presence of parent unless emancipated); Iowa, State v Means, 547 NW2d 615, 620 (Iowa App 1996) (noting that statute requires parent, guardian, or legal custodian's presence for juveniles under sixteen years of age); Kansas, Matter of B.M.B., 264 Kan 417, 955 P2d 1302, 1312-13 (1998) (holding that juvenile under fourteen years of age must be accompanied by interested adult to waive rights); Massachusetts, Commonwealth v A Juvenile (NO 1), 389 Mass 128, 449 NE2d 654, 657 (1983) (holding that juveniles under fourteen must be accompanied by interested adult to waive rights); Montana, Evans v Montana Eleventh Judicial Dist Court, 298 Mont 279, 995 P2d 455, 458 (2000) (applying statutory per se rule for defendants under sixteen years of age); North Carolina, NC Gen Stat Ann § 7B-2101 (Michie 1999) (disallowing waiver for juvenile under fourteen years without specific adult presence); Oklahoma, 10 Okla Stat Ann § 7303-3.1 (West 1998) (implementing per se rule for juveniles under sixteen); and West Virginia, Matter of Steven William T., $201 \mathrm{~W}$ Va 654, 499 SE2d 876, 884 (1997) (noting that West Virginia law requires parental presence for interrogations of juveniles under sixteen). 
waiver was knowingly, voluntarily, and intelligently made. ${ }^{61}$ In a sense, per se rules are only an addition to the totality of the circumstances rule, invalidating any waiver if two factors are present: (1) the accused is under a specified age and (2) no interested adult was present at the interrogation. But these two factors do not need to be met to invalidate a waiver if the totality of the circumstances suggests that the waiver was defective.

In some states, per se rules are statutory. For example, the Colorado Children's Code provides that statements made by a juvenile during a custodial interrogation are not admissible against the juvenile "unless a parent, guardian, or legal or physical custodian of the juvenile was present," and both the adult and the juvenile were made aware of their rights. ${ }^{62}$ Similarly, the Oklahoma Juvenile Code requires the presence and informed consent of both the juvenile and "the parents, guardian, attorney, adult relative, adult caretaker, or legal custodian of the child" in order to validate a waiver of the privilege against self-incrimination by a juvenile under the age of sixteen. ${ }^{63}$ In North Carolina a similar standard applies, but only to juveniles under the age of fourteen. ${ }^{64}$

In other states, per se rules are the product of judicial interpretations of state constitutions or of state juvenile procedure statutes. The Supreme Court of Kansas recently held that "a juvenile under 14 years of age must be given an opportunity to consult with his or her parent, guardian, or attorney as to whether he or she will waive his or her rights to an attorney and against self-incrimination." ${ }^{65}$ The Supreme Judicial Court of Massachusetts similarly held that no waiver by a juvenile under the age of fourteen could be effective without the presence of an interested adult. ${ }^{66}$ Several other states created per se rules in the wake of Gault, only to overturn them later.

61 See Schlam, 26 U Toledo L Rev at 915 (cited in note 57) (describing the operation of per se rules).

62 Col Rev Stat Ann § 19-2-511(1).

6310 Okla Stat Ann $\S 7303-3.1$.

64 NC Gen Stat Ann $\$ 7$ B-2101.

65 Matter of B.M.B., $955 \mathrm{P} 2 \mathrm{~d}$ at 1312-13.

66 A Juvenile (NO1), 449 NE2d at 657.

67 This has occurred in Georgia, Pennsylvania, and Louisiana. The cases establishing per se rules are Freeman $v$ Wilcox, 119 Ga App 325, 167 SE2d 163, 166-67 (1969); Commonwealth $v$ McCutchen, $463 \mathrm{~Pa}$ 90, 343 A2d 669, 670 (1975); and In Interest of Dino, 359 S2d 586, 594 (La 1978). The cases switching to totality rules are Riley $v$ State, 237 Ga 105, 226 SE2d 922, 926 (1976); Commonwealth v Williams, 504 Pa 511, 475 A2d 1283, 1287-88 (1984); and State v Fernandez, 712 S2d 485, 490 (La 1998). 


\section{Definitions of "Interested Adult"}

Factors such as the relationship between an interested adult and a juvenile, the intelligence of an interested adult, or a conflict of interest between a juvenile and an interested adult can affect the validity of a juvenile's waiver of rights. Conflicts of interest between adults and juveniles have often been ignored. Part I.C.1 discusses the grounds on which a juvenile can challenge the competency of an interested adult. Part I.C.2 looks at conflicts of interest in particular, and shows how courts have misunderstood them.

1. Grounds for challenging the competency of an interested adult.

In situations where an adult other than a member of the police or prosecution was present at the custodial interrogation of a juvenile, challenges by the juvenile to the admission of evidence based on the incompetency of the adult can be roughly grouped into three categories: (1) challenges based on an insufficiently close bond between the adult and the juvenile (a lack of interest) ${ }^{68}(2)$ challenges based on the adult's failure to understand the situation; ${ }^{69}$ and (3) challenges based on a conflict of interest between the juvenile and the adult. ${ }^{70}$ Although the first two categories present interesting legal questions, the close relationship test that this Comment proposes is only relevant to the third category of challenges."

These challenges are relevant both to federal and state inquiries under the totality of the circumstances standard, and to state inquiries in per se rule jurisdictions. Of course, a challenge is more likely to decide the case in a per se rule jurisdiction than in a totality of the circumstances jurisdiction. In a per se rule jurisdiction, proof of the incompetency of the interested adult will invalidate the juvenile's waiver of the privilege against self-incrimination. ${ }^{2}$ In a totality of the circumstances jurisdiction, proof of the incompetency of the interested adult will be only one factor to be weighed along with all the other circumstances. $^{13}$

68 See, for example, Commonwealth v Smith, $472 \mathrm{~Pa} 492,372$ A2d 797, 801 (1977) ("If the adult is one who is not concerned with the interest of the minor, the protection sought to be afforded is illusory.").

69 Empirical evidence suggests that adults frequently misunderstand their Miranda rights, although they are somewhat more likely to understand them than are juveniles. See Thomas Grisso, Juveniles' Capacities to Waive Miranda Rights: An Empirical Analysis, 68 Cal L Rev 1134, 1151-52,1160-61 (1980).

70 See Little v Arkansas, 435 US 957 (1978) (Marshall dissenting from denial of certiorari).

71 See Part III.

72 See Part I.B.2.

73 See Parts I.A.2 and I.B.1. 
2. Challenges based on a conflict of interest between the juvenile and the adult.

Although the Supreme Court has not applied its totality of the circumstances test to an interested adult since Fare, or specifically addressed the question of what factors should be considered when deciding the presence or competence of an interested adult, in Little $v$ Arkansas, ${ }^{74}$ Justice Marshall, joined by Justice Brennan, dissented from the denial of certiorari in a case in which a thirteen-year-old girl had been convicted of murder. ${ }^{75}$ The prosecution's case had depended heavily on a confession obtained from the girl on the day of the murder. $^{76}$ Prior to making the confession, the girl had met alone with her mother, the wife of the murder victim, who had previously been questioned by the police and who believed that she was herself a suspect." When the mother emerged from this meeting, she stated that the girl wanted to confess. ${ }^{78}$ The girl was then advised of her Miranda rights, waived her rights, and confessed, all in the presence of her mother and the police.

Justice Marshall, citing Haley, Gallegos, and Gault, acknowledged the usefulness, in most circumstances, of the presence of an interested adult during the custodial interrogation of a juvenile. ${ }^{80}$ In this particular case, "[t]he mother, however, was plainly not in a position to provide rational advice with only the child's interests in mind, especially on the day of the murder."

Justice Marshall recognized that,

to uphold a child's waiver on the ground that she received parental advice is surely questionable when the parent has two obvious conflicts of interest, one arising from the possibility that the parent herself is a suspect, and the other from the fact that she is "advising" the person accused of killing her spouse.

Justice Marshall was concerned that an accused juvenile might not receive the proper level of protection from an adult who is herself a suspect in the crime or who has strong ties to the victim of the crime.

State courts disagree over how to determine when a conflict of interest exists between a juvenile and an otherwise interested adult.

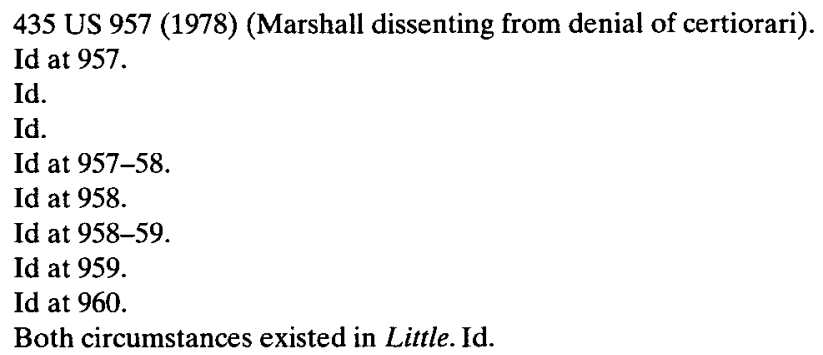


The Supreme Court of Appeals of West Virginia has thrown out a juvenile's confession where the interested adult had an intimate relationship with another suspect in the case. ${ }^{84}$ The Supreme Judicial Court of Massachusetts, in contrast, requires that an interested adult actually be antagonistic to the juvenile in order to invalidate the juvenile's confession.

In the case of Matter of Steven William $T .,{ }^{86}$ which arose in West Virginia, Steven's aunt had confessed to a murder, and implicated Steven as an accessory. ${ }^{87}$ Steven admitted a small role in the murder during a custodial interrogation, at which a close adult friend of the family, Ms. Whetzel, was present. ${ }^{88}$ Later, at another interview where both Ms. Whetzel and Steven's biological mother were present, he admitted having shot the victim. ${ }^{89}$ He subsequently repudiated this statement and claimed that Ms. Whetzel had pressured him into making it."

The Supreme Court of Appeals of West Virginia found the confession inadmissible. ${ }^{91}$ Despite a parent or guardian's presence, a confession "may be rendered meaningless where the parent or guardian has a conflict of interest with the child or has no real parental relationship with the child, as was the case here where the biological mother had not seen the child in four years." ${ }^{92}$ The potential conflict of interest in this case arose from Steven's contention "that Ms. Whetzel pressured him into confessing to the murder in order to protect [his aunt], the woman with whom Ms. Whetzel allegedly maintained an intimate relationship." "In response, the court formulated the following conflict rule:

[W] here law enforcement authorities seeking to interrogate a juvenile have knowledge regarding a potential conflict of interest between parent (or custodian) and child with respect to the matters which are the subject of the interrogation, such law enforcement authorities must make further inquiry regarding the appropriate person to be present with the juvenile.

See text accompanying notes $86-94$.

See text accompanying notes $95-112$.

201 W Va 654, 499 SE2d 876 (1997).

Id at 879 .

88 Id.

89 Id at 880 .

90 Id at 881 .

91 Although the court discusses the voluntariness of the confession for several pages, it appears to base its holding on the failure of the police to promptly present Steven to a magistrate. Id at 883 ("While we invalidate the confession based upon our prompt presentment discussion above, we also address several unorthodox facets of Steven's confession to murder.").

92 Id at 884-85.

93 Id at 886 .

94 Id. 
In contrast to West Virginia, the Supreme Judicial Court of Massachusetts has set a less protective standard for challenges based on a conflict of interest. Massachusetts employs a per se rule requiring the presence of an adult to validate a juvenile waiver of the privilege against self-incrimination if the juvenile is under fourteen. ${ }^{95}$ The accused in Commonwealth $v$ Philip $S^{\%}$ was twelve years old when the police questioned him about his involvement in starting a fire that led to the death of a firefighter. ${ }^{97}$ His mother was present at his interrogation, and both he and his mother were read complete Miranda warnings and indicated that they understood their rights. ${ }^{98}$ The juvenile's mother repeatedly encouraged him to tell the truth, and when at one point the juvenile became angry and ran out of the room, his mother brought him back. ${ }^{99}$ The juvenile, along with his mother, eventually initialed an inculpatory statement. ${ }^{100}$ When the interview was over, the mother did not want her son to return home with her, so a social worker arranged for the juvenile to stay in a juvenile home.

The Supreme Judicial Court overturned the lower court's finding that the juvenile's mother was not an "interested adult":

We reject the notion that a parent who fails to tell a child not to speak to interviewing officials, who advises the child to tell the truth, or who fails to seek legal assistance immediately is a disinterested parent. Our interested adult rule, which we conclude was satisfied in this case, is not violated because a parent fails to provide what, in hindsight and from a legal perspective, might have been optimum advice.

Although the outcome in Philip $S$. differs from that in Steven William $T$., there was no showing in Philip $S$. of an actual conflict of interest between Philip and his mother, ${ }^{103}$ as there was in Steven William T.

95 For juveniles over the age of fourteen Massachusetts courts apply a totality of the circumstances test. See Commonwealth v A Juvenile (NO1), 389 Mass 128, 449 NE2d 654 (1983):

We conclude that, for the Commonwealth successfully to demonstrate a knowing and intelligent waiver by a juvenile, in most cases it should show that a parent or an interested adult was present, understood the warnings, and had the opportunity to explain his rights to the juvenile so that the juvenile understands the significance of waiver of these rights. For the purpose of obtaining the waiver, in the case of juveniles who are under the age of fourteen, we conclude that no waiver can be effective without this added protection.

Id at 657 .

96414 Mass 804, 611 NE2d 226 (1993).

97 Id at 228.

98 Id at 229.

99 Id.

100 Id at 230.

101 Id.

102 Id at 231.

103 The court noted: 
Thus, under Massachusetts law, an interested adult need not fulfill the role of counsel for the juvenile; it is sufficient if the adult has the capacity to understand the situation and is not "actually antagonistic" to the juvenile. ${ }^{104}$

The Massachusetts Supreme Judicial Court elaborated on this standard in Commonwealth $v \mathrm{McCra}{ }^{105}$ The defendant in that case was a fifteen-year-old boy who confessed to murdering his father, mother, and sister, and was convicted. ${ }^{106}$ The boy's aunt was present during his entire interrogation. ${ }^{107}$ Because the defendant was over the age of fourteen, under Massachusetts law he was only required to have an "opportunity to consult with an interested adult," but the defense claimed on appeal that "he was deprived of a meaningful opportunity to consult with an interested adult because of his aunt's close relationship to the victims and her concern over what happened to them." The court rejected this argument. Citing Philip S., the court stated:

We do not hold a parent or an interested adult to the standards to which we would hold lawyers in explaining a defendant's rights and the possible consequences of waiver. The fact that the defendant's aunt was the sister of one of the victims does not require the conclusion that she would be unable to act as an interested adult. ${ }^{109}$

The $\mathrm{McCra}$ decision reaches the opposite conclusion from the West Virginia decision. In Steven William T., Ms. Whetzel's "intimate relationship" with another suspect in the case made her incompetent to act as an interested adult during custodial interrogations of Steven because it constituted a "potential conflict of interest" under West Virginia law. ${ }^{110}$ In contrast, the defendant's aunt in $\mathrm{McCra}$ was held competent to serve as an interested adult despite the fact that one of

There is no objective basis in the record to support a finding that interviewing officials could have concluded that Mrs. Smith was antagonistic toward her son. She appeared concerned about her son, not angry with him, attended both interviews, and was attentive to the administration of Miranda warnings and provisions about waiving rights.

Id.

104 Id. The court stated:

If ... it should have been reasonably apparent to the officials questioning a juvenile that the adult who was present on his or her behalf ... was actually antagonistic toward the juvenile, a finding would be warranted that the juvenile has not been assisted by an interested adult and did not have the opportunity for consultation contemplated by our rule.

Id.

105427 Mass 564, 694 NE2d 849 (1998).

106 Id at 850 .

107 Id at 851.

108 Id.

109 Id at 852-53 (citations omitted).

110499 SE2d at 886. 
the victims was her sister." This relationship did not make the aunt "actually antagonistic" under Massachusetts law."

A conflict of interest standard such as the one utilized in Steven William $T$. is desirable for several reasons. Like per se rules requiring an interested adult, a conflict of interest standard would reduce confusion in application by the police and force courts to be more vigilant in guarding against coerced confessions. ${ }^{113}$ It would focus attention on a problem that courts and the police often overlook in determining the voluntariness of juvenile confessions. West Virginia's consideration of an interested adult's "intimate relationship" with another suspect suggests the approach explored in Part II: the close relationship standard of negligent infliction of emotional distress.

\section{NEGLIGENT INFLICTION OF EMOTIONAL DISTRESS AND THE "CLOSE RELATIONSHIP" STANDARD}

This Part first examines negligent infliction of emotional distress, which different jurisdictions have limited by requiring plaintiffs to show either a physical impact, presence in a zone of danger, or a close relationship with the victim of physical harm. This Part then examines particular relationships that have or have not been defined as close, and shows that close relationships have been limited to immediate family relationships or, in some jurisdictions, similarly strong relationships.

\section{A. Negligent Infliction of Emotional Distress}

A plaintiff in a suit for negligent infliction of emotional distress seeks to recover damages for mental or emotional harm, rather than physical harm, that resulted from the defendant's negligence. ${ }^{114} \mathrm{Negli}-$ gent infliction of emotional distress differs from more conventional pain and suffering damages. Pain and suffering refers to mental or emotional harms that stem directly from a physical injury. ${ }^{115}$ Negligent infliction of emotional distress refers to wrongdoing that causes mental or emotional harm, which may manifest itself in physical symptoms, but which does not result from physical injury to the person suffering it. ${ }^{16}$

111 McCra, 694 NE2d at 853 .

112 Id.

113 See text accompanying notes 58-59.

114 See Consolidated Rail Corp v Gottshall, 512 US 532, 544 (1994) (defining "negligent infliction of emotional distress"). 
Wrongdoing may cause emotional injuries that are very remote in time or space from the conduct that caused them. ${ }^{117}$ Courts have worried that negligent infliction of emotional distress could result in nearly infinite liability for defendants, and have sought to limit the class of plaintiffs that can recover for emotional and mental harms. ${ }^{11}$ Today there are three competing tests which different jurisdictions require a plaintiff to meet to recover for negligent infliction of emotional distress: (1) the physical impact test, (2) the zone of danger test, and (3) the relative bystander test."

Of the three tests, the physical impact test places the highest burden on plaintiffs. ${ }^{120}$ Under this test, in order to recover for emotional or mental harm, the plaintiff must demonstrate that he received a physical impact or injury at the same time as he received the emotional or mental harm. ${ }^{121}$ Five states currently use the physical impact test under certain circumstances. ${ }^{122}$

The zone of danger test allows plaintiffs to recover under a broader range of circumstances. Under this test, a plaintiff may recover for emotional or mental harm if he demonstrates that the defendant's negligent conduct either physically impacted him or placed him in immediate risk of physical harm. ${ }^{123}$ Fourteen jurisdictions use the zone of danger rule, ${ }^{124}$ and the Supreme Court has held that the zone of danger rule applies to claims under the Federal Employer's

117 Id at 545 .

118 Id at 546 .

119 See id at $546-48$.

120 Id at 547.

121 Id.

122 The states are Florida, R.J. v Humana of Florida, Inc, 652 S2d 360, 362 (Fla 1995); Georgia, Lee v State Farm Mutual Insurance Co, 272 Ga 583, 533 SE2d 82, 84 (2000); Indiana, Shuamber v Henderson, 579 NE2d 452, 454 (Ind 1991); Kentucky, Deutsch v Shein, 597 SW2d 141, 14546 (Ky 1980); and Oregon, Hammond v Central Lane Communications Center, 312 Or 17, 816 P2d 593, 597 (1991). Some of these states have carved out significant exceptions to the physical impact rule. See Jacob A. Stein, 2 Stein on Personal Injury Damages § 10:31 n 27 (3d ed 1997).

123 See Consolidated Rail, 512 US at 547-48.

124 The jurisdictions are Arizona, Keck v Jackson, 122 Ariz 114, 593 P2d 668, 670 (Ariz 1979); Colorado, Towns v Anderson, 195 Colo 517, 579 P2d 1163 (1978); Delaware, Robb v Pennsylvania Railroad Co, 58 Del 454, 210 A2d 709, 714-15 (1965); District of Columbia, Williams v Baker, 572 A2d 1062, 1064 (DC App 1990); Illinois, Rickey v Chicago Transit Authority, 98 III 2d 546, 457 NE2d 1, 5 (1983); Maryland, Resavage v Davies, 199 Md 479, 86 A2d 879, 880 (1952); Minnesota, Stadler v Cross, 295 NW2d 552, 554 (Minn 1980); Missouri, Asaro v Cardinal Glennon Memorial Hospital, 799 SW2d 595, 599 (Mo 1990); New York, Bovsun v Sanperi, 473 NYS2d 357, 461 NE2d 843, 846 (1984); North Dakota, Whetham v Bismarck Hospital, 197 NW2d 678 (ND 1972); Tennessee, Ramsey v Beavers, 931 SW2d 527, 531 (Tenn 1996); Utah, Boucher v Dixie Medical Center, 850 P2d 1179, 1181 (Utah 1992); Vermont, Jobin v McQuillen, 158 Vt 322, 609 A2d 990,993 (1992); and Wisconsin, Garrett v City of New Berlin, 122 Wis 2d 223,362 NW2d 137, 141-42 (Wis 1985). See Stein, 2 Personal Injury Damages \$10:33 n 42 (cited in note 122). 
Liability Act. ${ }^{125}$ Some jurisdictions modify the rule to include a requirement of a close relationship to the victim of physical harm. ${ }^{126}$

The relative bystander test, the broadest of the three tests, was first employed in 1968 by the California Supreme Court in Dillon $v$ Legg. ${ }^{127}$ The court held that a woman who suffered emotional and physical harm when she witnessed the negligently inflicted death of her daughter could recover for her damages, even though she was outside the zone of danger. ${ }^{128}$ The court held that reasonable foreseeability should determine whether a plaintiff could recover for emotional harm, and listed three factors to consider in determining foreseeability:

(1) Whether plaintiff was located near the scene of the accident as contrasted with one who was a distance away from it. (2) Whether the shock resulted from a direct emotional impact upon plaintiff from the sensory and contemporaneous observance of the accident, as contrasted with learning of the accident from others after its occurrence. (3) Whether plaintiff and the victim were closely related, as contrasted with an absence of any relationship or the presence of only a distant relationship.

Under this test, defendants have a duty to prevent foreseeable emotional injuries, ${ }^{130}$ and a plaintiff only needs to show that her emotional injuries were foreseeable and caused by the defendant's negligent conduct in order to recover. ${ }^{131}$ Nearly half the states now utilize some form of the relative bystander rule."

\section{B. The "Close Relationship" Standard}

In those jurisdictions which utilize the relative bystander test, courts in negligent infliction of emotional distress cases must examine the relationship between the victim of the physical injury and the plaintiff to determine whether any emotional injury to the plaintiff was foreseeable. $^{133}$ In jurisdictions that add a close relationship requirement to the zone of danger rule, courts must perform the same inquiry. ${ }^{134}$ Some relationships are uniformly considered close, some re-

125 See Consolidated Rail, 512 US at 557.

126 See, for example, Keck, $593 \mathrm{P} 2 \mathrm{~d}$ at 670 (requiring close relationship in conjunction with zone of danger test in Arizona).

12768 Cal 2d 728, 441 P2d 912 (1968).

128 Id at $914,924-25$.

129 Id at 920.

130 Id.

131 Id at 919-21.

132 See Consolidated Rail, 512 US at 549 n 10.

133 See text accompanying notes $127-32$.

134 See text accompanying note 126. 
lationships are never considered close, and some relationships fall in between.

Courts uniformly agree that certain relationships between immediate family members always constitute close relationships for purposes of determining forseeability. ${ }^{135}$ A parent, ${ }^{1.36}$ child, ${ }^{137}$ sibling, ${ }^{138}$ or spouse $^{139}$ of the victim will always meet the close relationship standard.

Courts also uniformly agree that certain relationships can never constitute a close relationship for purposes of determining foreseeability. No court has allowed a plaintiff to recover for emotional injury resulting from witnessing physical harm to a complete stranger. ${ }^{140} \mathrm{Re}-$ lationships between friends or co-workers are also never classified as close. $^{141}$

There are certain relationships which some jurisdictions consider close relationships and which other jurisdictions do not. Unmarried but romantically involved partners may have a close relationship in some jurisdictions, ${ }^{142}$ while in others they may not. ${ }^{143}$ The same is true

135 See David Sampedro, When Living as Husband and Wife Isn't Enough: Reevaluating Dillon's Close Relationship Test in Light of Dunphy v. Gregor, 25 Stetson L Rev 1085, 1101 n 88 (1996) (surveying cases accepting immediate family relationships as close relationships).

136 See, for example, Bowen v Lumbermens Mutual Casualty Co, 183 Wis 2d 627, 517 NW2d $432,445-46$ (1994) (holding that mother could recover for emotional injury resulting from son's death when hit by automobile); Matthews $v$ Amberwood Associates Ltd Partnership, 351 Md 544, 719 A2d 119, 133-34 (1998) (allowing mother to recover for emotional injury when son was killed by pit bull).

137 See, for example, Jones $v$ Sanger, 204 W Va 333, 512 SE2d 590, 595 (1998) (holding that son who witnessed mother's death in car accident could recover for negligent infliction of emotional distress); Grandstaff v City of Borger, Texas, 767 F2d 161, 172 (5th Cir 1985) (finding that stepsons have close relationship with stepfather under Texas law).

138 See, for example, Goncalvez v Patuto, 188 NJ Super 620, 458 A2d 146, 151 (1983) (finding that "fraternal relationship presumptively qualifies" as close relationship); Kelly v Bass Enterprises Production Co, 17 F Supp 2d 591, 598 (E D La 1998) (noting that Louisiana law allows brother to recover for negligent infliction of emotional distress).

139 See, for example, Kraszewski v Baptist Medical Center of Oklahoma, Inc, 916 P2d 241, 247 (Okla 1996) (finding that husband has close relationship); Ledford v Delta Airlines, Inc, $658 \mathrm{~F}$ Supp 540, 543 (S D Fla 1987) (finding that spouse meets close relationship test under Florida law).

140 See, for example, Devereux v Allstate Insurance Co, 557 S2d 1091, 1098 (La App 1990) (finding relationship with victim whom plaintiff "barely knew at sight" too distant for close relationship); Migliori v Airborne Freight Corp, 426 Mass 629,690 NE2d 413, 418 (1998) (holding that stranger who attempted to rescue victim of physical injury could not recover for negligent infliction of emotional distress).

141 See, for example, Hislop v Salt River Project Agr Improvement and Power Dist, 197 Ariz 553, 5 P3d 267, 272 (Ariz App 2000) (holding that coworker and friend could not recover for negligent infliction of emotional distress). Some dissenting judges have argued that whether a relationship between friends or coworkers is close should be a question of fact to be determined case by case. See id at 276 (Garbarino dissenting) (arguing that closeness should be a jury question); Smith v Kings Entertainment Co, 99 Ohio App 3d 1, 649 NE2d 1252, 1254 (1994) (Bettman dissenting) (arguing that closeness of relationship should have "a bearing only on the extent of [the plaintiff's] damages, not on her right to recover").

142 See, for example, Dunphy v Gregor, 136 NJ 99, 642 A2d 372, 380 (1994) (plaintiff could recover for emotional injury resulting from death of fiancée where the two cohabited and had an 
for aunts, uncles, nieces, and nephews, ${ }^{144}$ and also for cousins. ${ }^{145}$ In these situations, whether a relationship is close depends on the facts of a particular case in some jurisdictions, while in other jurisdictions relationships outside the immediate family can never be classified as close.

\section{APPLYING THE "ClOSE RELATIONSHIP" STANDARD TO CONFLICTS OF INTEREST}

This Part first describes the operation of the proposed close relationship standard and summarizes its advantages. Then Part III.B suggests an alternative "immediate family" standard for jurisdictions where negligent infliction of emotional distress law is undeveloped. Part III.C examines problems with the close relationship standard and alternative proposals, and finally Part III.D applies the standard to two cases.

\section{A. Advantages of Applying the Close Relationship Standard in Juvenile Interrogation Cases}

Stated generally, this Comment proposes that when determining whether or not an interested adult has a conflict of interest, a court should apply its jurisdiction's close relationship standard from torts to the relationships between the interested adult and all the victims and other suspects in the crime of which the juvenile is accused. If any of the relationships meet the close relationship test, it would show that the interested adult has a significant conflict of interest, which should weigh against the admissibility of statements made by the juvenile under the adult's care. In jurisdictions where an interested adult is per se required, a close relationship would invalidate the juvenile's waiver and make any of the juvenile's statements under the waiver inadmissible. In jurisdictions where the presence of an interested adult is only one factor to be considered in the totality of the circumstances, a close

intimate familial relationship).

143 See, for example, Elden $v$ Sheldon, $46 \mathrm{Cal} 3 \mathrm{~d}$ 267, 758 P2d 582, 586 (1988) (holding that plaintiff could not recover for emotional distress resulting from physical injury to person with whom he cohabitated and had a relationship akin to marriage).

144 Compare Kriventsov v San Rafael Taxicabs, Inc, 186 Cal App 3d 1445, 229 Cal Rptr 768, 770 (1986) (finding uncle's relationship with nephew close for purposes of negligent infliction of emotional distress, where uncle and nephew were related by blood and lived in the same household), with Trombetta $v$ Conkling, 187 AD2d 213, 593 NYS2d 670, 671 (1993) (holding that niece could not sue for emotional distress on the basis of physical injury to her aunt, despite their intimate relationship).

145 Compare Trapp v Schuyler Construction, 149 Cal App 3d 1140, 197 Cal Rptr 411, 412 (1983) (holding that relationship between first cousins did not qualify as close), with Barnhill $v$ Davis, 300 NW2d 104, 108 (Iowa 1981) (extending close relationship status to all persons "related within the second degree of consanguinity or affinity"). 
relationship would weigh in favor of finding the waiver invalid and the statements inadmissible.

The types of relationships that suffice to award damages to bystanders of accidents should disqualify anyone with such a relationship to a victim of the accident from advising the person accused of committing the accident, given the closeness of the relationship and the intensity of the emotions involved. One court has said of emotional distress:

It is the presence of deep, intimate, familial ties between the plaintiff and the physically injured person that makes the harm to emotional tranquility so serious and compelling. The genuine suffering which flows from such harm stands in stark contrast to the setbacks and sorrows of everyday life, or even to the apprehension of harm to another, less intimate person.

This idea that certain "intimate, familial ties" can give rise to a unique form of "genuine suffering" seems equally applicable whether the injury in question happens to be classified in a given legal proceeding as a tort, as in emotional distress litigation, or a crime, as in juvenile interrogations.

This standard has the advantage of providing a clear rule to the police when deciding whom to have present at the interrogation of a juvenile. As long as the police follow the procedure set forth in the rule, the police will know as soon as they begin an interrogation that any statements made will not be thrown out of court on the basis of a conflict of interest. The police simply can ask the interested adult, before beginning questioning, what his or her relationship is to the other suspects in the crime, if there are any, and to the victims of the crime. ${ }^{147}$ The police could be kept informed of the conflict of interest standard with a simple information card. Many jurisdictions already use such cards to aid the police in explaining rights to suspects, or use special forms to ensure that juveniles fully understand their rights, so it would not be expensive or burdensome to add the conflict of interest standard. If the interested adult has a close relationship with any of the suspects or victims, the police would then need to find another adulttypically a parent, guardian, or adult family member-with no such close relationships to serve as the interested adult.

146 Portee v Jaffee, 84 NJ 88, 417 A2d 521, 526-27 (1980).

147 The approach suggested by this Comment takes for granted that an adult who is herself a victim of the crime or a suspect in the crime should not be competent to act as an interested adult. Although it might seem absurd that a victim of a crime could potentially be in the position of serving as an interested adult and advising the juvenile accused of the very same crime, the possibility is not foreclosed by the case law. 
If no interested adult without close relationships to victims or other suspects can be found, the next action of the police would depend on the jurisdiction. In a totality of the circumstances jurisdiction, the police might have the option of proceeding with the interrogation without any interested adult. If there were no other defects in the interrogation, the accused's statements would very likely be admissible. ${ }^{148}$ In a per se rule jurisdiction, proceeding with the interrogation without an interested adult would have little purpose, as any statements made would be inadmissible. ${ }^{149}$ The juvenile would have to be appointed an attorney or a guardian ad litem. This also would be an option in a totality of the circumstances jurisdiction if the surrounding circumstances indicated a likelihood of involuntariness absent the presence of an adult.

Another argument in favor of this standard is that it would create consistency among different areas of the law. If an adult has a close enough relationship with a person to sue for emotional distress in tort for an injury caused to that person, common sense suggests that he should not be held competent to advise a child, if that child is accused of committing that person's injury. A similar analysis applies to persons suspected of a crime. It seems intuitive that the definition of "close relationship" should be the same whether arising in criminal procedure or in tort law.

It is important to note that the standard this Comment advocates does not require a juvenile to show that the interested adult present at her interrogation in fact could have sued the juvenile for negligent infliction of emotional distress and successfully recovered. Such a requirement would place a very high burden on the juvenile for excluding statements made by reason of an invalid waiver. A juvenile would not, under the standard proposed by this Comment, have to prove the other elements of negligent infliction of emotional distress, such as causation and damages. This Comment's approach does not intend to borrow the entire negligence action for infliction of emotional distress; it only borrows that portion aimed at defining close relationships. Thus a juvenile would only need to show that the adult's relationship with a victim or other suspect could satisfy the close relationship element of infliction of emotional distress.

148 See Parts I.A.2 and I.B.1.

149 See Part I.B.2.

150 See Jay W. Stein, The Hobgoblin Doctrine: Identifying "Foolish" Consistency in the Law, 29 Tex Tech L Rev 1017, 1017-22 (1998) (noting that consistency has been the rationale behind diverse legal doctrines such as stare decisis and the Uniform Commercial Code); John E. Coons, Consistency, 75 Cal L Rev 59, 59-60 (1987) (discussing the Aristotelian maxim that "like cases should be treated alike"). 
It also should be emphasized that this approach is not intended to be the exclusive means of testing the competency of an interested adult. The close relationship approach furnishes a test for eliminating the most egregious cases of conflict of interest only; it does not displace other means of testing adult competency or conflicts of interest arising from other sources. A person may still be incompetent to serve as an interested adult, even if he has no conflict of interest, if he has an insufficiently close bond with the juvenile or if he is unable to understand the proceedings. ${ }^{1.1}$ In addition, conflicts of interest between parent and child may also exist outside the context of close relationships with victims or other suspects. ${ }^{152}$

\section{B. Adopting Widely Accepted Close Relationships}

The most significant difficulties with the approach suggested above is the lack of well-developed emotional distress law in some jurisdictions and the explicit rejection of the tort of negligent infliction of emotional distress in others. ${ }^{153}$ In those jurisdictions, applying the close relationship standard of emotional distress will be either fruitless or impossible.

As a simplified alternative, this Comment proposes that "close relationship" can be defined for the purposes of investigating conflicts of interest as any relationship between immediate family members; that is, a relationship between a parent or guardian and a child, a relationship between brothers and sisters, or a marital relationship. These relationships have universally been accepted as close relationships by those courts that make close relationship determinations in negligent infliction of emotional distress cases. ${ }^{154}$ There are obvious problems with this definition. The definition will frequently be either overinclusive or underinclusive, as an immediate family relationship is no guarantee of an actual close relationship, and actual close relationships often exist outside of the traditional immediate family. ${ }^{155}$ But this approximates the definition chosen by many states that have considered

151 Thus the close relationship test only applies to the third category of interested adult challenges mentioned in Part I.C.1, not to the first two. See text accompanying notes 68-70.

152 See, for example, In re Ricky H., 2 Cal 3d 513, 468 P2d 204, 210-11 (1970) (finding waiver ineffective because juvenile waived right to counsel rather than cause his father to go further into debt to the county).

153 See Sampedro, 25 Stetson L Rev at 1100-01 n 87 (cited in note 135) (surveying states that have rejected the relative bystander test in favor of the zone of danger test).

154 See Part II.B.

155 See Laura M. Raisty, Note, Bystander Distress and Loss of Consortium: An Examination of the Relationship Requirements in Light of Romer v. Evans, 65 Fordham L Rev 2647, 2659-64 (1997) (critiquing courts' formalist definition of close relationships that limits such relationships to the nuclear family and finding a functional definition to be more appropriate). 
the issue, and despite its defects, its simplicity may make it superior to the state-by-state approach advocated above. ${ }^{156}$

As appealing as the simplicity of the immediate family standard may be, there are several reasons why it should only be applied in those jurisdictions that lack their own body of close relationship law. First, unless the jurisdiction happens to also define close relationships as immediate family for emotional distress, the consistency rationale of the close relationship standard would be entirely eliminated. Second, the close relationship approach allows a state to base its conflict of interest standard on its own emotional distress law, rather than on a conglomeration of many states' decisions. This allows the close relationship approach to be more flexible and allows more innovation than an immediate family approach. Finally, the immediate family approach includes only the most intimate relationships that have been universally recognized by the courts as "close." Some states have more broadly recognized intimate relationships as close, and those relationships should also be included in the conflict of interest standard.

\section{Potential Difficulties and Counterproposals}

It might be argued that the close relationship approach would leave open the possibility that an adult might not reveal a relationship with a suspect or a victim. But the police would still have the option under this approach of finding another interested adult if they have some reason for believing that the adult has a conflict of interest, which presumably they would do if they intend for the juvenile's statements to be admissible. Also, a court would not be obligated to admit statements made after a waiver if it felt that the guidance provided by the adult was tainted by a conflict of interest. Difficulties might arise in situations where a suspect or a victim is not identified until after the interrogation of the juvenile. But in most such cases the adult would presumably be just as unaware of this potential conflict as the police, and therefore not subject to any actual conflict of interest.

Another potential standard which some might advocate, the conflict of interest rules for attorneys, ${ }^{157}$ is unworkable for several reasons. Many rules applicable to attorneys would be irrelevant or nonsensical when applied to interested adults. ${ }^{158}$ Perhaps more importantly, at least

156 See John S. Herbrand, Annotation, Relationship Between Victim and Plaintiff-Witness as Affecting Right to Recover Damages in Negligence for Shock or Mental Anguish at Witnessing Victim's Injury or Death, 94 ALR3d 486 (1979) (surveying close relationship cases, which have generally held that immediate family relationships qualify and other relationships do not).

157 See American Bar Association Model Rules of Professional Conduct and Code of Judicial Conduct Rule 1.7 (1983) (reviewing when a lawyer should not represent a client due to a conflict of interest).

158 The portion of the rule requiring client consent after consultation, Rule 1.7(b)(2), would 
one state court has specifically said that standards for attorneys would be inappropriate in the context of interested adults. ${ }^{159}$

It also might be objected that this Comment's close relationship approach would insufficiently protect juvenile rights if it allowed, for example, the cousin of a murder victim to advise the accused murderer as to his privilege against self-incrimination. ${ }^{160}$ One response to this objection is that the fault lies with tort law, and that tort law should be modified to expand the concept of close relationships in negligent infliction of emotional distress cases. But in addition, even where tort law defines close relationships narrowly, this Comment's approach must be considered in the context of the totality of the circumstances standard. The Constitution invalidates any waiver made when the totality of the circumstances suggests it was not knowing, voluntary, and intelligent. This approach would not lessen that protection. At the very least, this Comment's approach would eliminate the most egregious cases of conflicts of interest, although it might leave the closest cases, in some jurisdictions, to the totality of the circumstances test.

\section{Examples of the Application of the Close Relationship Standard}

It may be useful to illustrate this approach by applying it to the facts of Little and $\mathrm{McCra}{ }^{161}$ In Little, the defendant's mother was "emotionally distraught [and] crying" at the time she was expected to be advising her daughter. ${ }^{162}$ These reactions are not unlike those found in a typical infliction of emotional distress suit. ${ }^{163}$ Under the close relationship standard, the statements made in Little would be excluded as the product of an invalid waiver. The interested adult present was the juvenile's mother, and the mother's husband was the victim of the juvenile's suspected crime. As a spouse, Little's mother has a sufficiently close relationship with her husband to meet the close relationship

be particularly troublesome. It is hard to imagine a parent or relative with no training in the law calmly discussing the potential conflict he has with the accused juvenile, and then receiving meaningful consent.

159 See Philip S., 611 NE2d at 232 n 6 ("[W]e cannot hold a parent or an interested adult to the standards to which we would hold lawyers in explaining a defendant's rights and the possible consequences of waiver.").

160 See, for example, Trapp v Schuyler Construction, 149 Cal App 3d 1140, 197 Cal Rptr 411, 412 (1983) (holding that first cousins do not have a close relationship). Such a narrow interpretation of "close" would permit a murder victim's cousin to act as an interested adult under this Comment's proposed test.

161 See Part I.C.2.

162435 US at 960.

163 Of course, many interested adult cases are not similar to emotional distress suits. Potential interested adults often will not have witnessed the crime at issue, or will not have suffered sufficient emotional distress to recover damages. This Comment does not limit its anaiysis, however, to cases as strong as the defendant's in Little. 
prong of negligent infliction of emotional distress. ${ }^{164}$ Although Arkansas does not recognize negligent infliction of emotional distress as a cause of action, ${ }^{165}$ a spouse would meet the alternative "immediate family" standard of this Comment's approach. Thus the close relationship of Little's mother to the victim should make her incompetent to serve as the juvenile's interested adult, by way of conflict of interest.

$\mathrm{McCra}$ is a similar case. The interested adult was the sister of one of the victims. ${ }^{160}$ Under this Comment's approach, the validity of the juvenile's waiver would depend in part upon whether the jurisdiction considers a relationship between sisters a close relationship for the purposes of negligent infliction of emotional distress claims. Massachusetts holds that the parent-child relationship and the spousal relationship are close relationships, ${ }^{167}$ as is a cohabitation relationship, ${ }^{168}$ but no court in that state has ruled on the specific question of a relationship between sisters. As in Little, the immediate family standard would fill in the gaps where state law has not yet ruled. Sisters are always considered closely related in negligent infliction of emotional distress cases, so McCra's aunt would be incompetent to function as an interested adult for McCra.

The outcome in the case would also depend upon whether the jurisdiction is a per se or a totality of the circumstances jurisdiction. Massachusetts applies a totality of the circumstances rule to defendants of McCra's age, so the statements might be admissible even if the interested adult were found incompetent. In a per se jurisdiction, the waiver would be invalid if a conflict were demonstrated.

\section{CONCLUSION}

Courts recognize the value of the presence of an interested adult during custodial interrogations of juveniles by the police. An adult serves to explain rights to the juvenile which she may not understand, to bolster the juvenile's confidence in an emotionally difficult situa-

164 As in many jurisdictions, Arkansas's law in this area is not well developed. See Herbrand, Annotation, 94 ALR3d at 487-88 (cited in note 156) (reviewing cases in which a spousal relationship fulfilled the relationship requirement to recover for emotional distress damages).

165 See Morgan v Batesville Casket Co, 1998 Ark App LEXIS 207, *5 (noting that "Arkansas courts do not recognize a cause of action for the negligent infliction of emotional distress"). Arkansas may be one of the only states not to do so. See Consolidated Rail Corp v Gottshall, 512 US 532, 545 n 3 (1994) (recognizing that Arkansas and Alabama have not clearly accepted negligent infliction of emotional distress).

$166 \mathrm{McCra}, 694 \mathrm{NE} 2 \mathrm{~d}$ at 851.

167 See Dziokonski v Babineau, 375 Mass 555, 380 NE2d 1295, 1302-03 (1978) (allowing a mother to sue for emotional distress damages after witnessing injuries to her minor child and permitting a husband to sue after learning about the death of his wife).

168 See Richmond $v$ Shatford, 1995 Mass Super LEXIS 440, *7-10 (holding that an extended cohabitation may be sufficient to establish a close relationship and that an immediate blood relation or affiliation is not mandatory). 
tion, and to witness and hopefully deter any abuses by the police. What courts often do not recognize is that an adult in the interrogation room will not always provide these benefits. Some adults may not understand the juvenile's rights any better than the juvenile does; some adults may have no interest in the juvenile's welfare. Worse, some adults may have interests that are antagonistic to the juvenile's. This Comment suggests a simple approach that can be used by the police and courts to help assure that such adults do not bring about unknowing, involuntary, or unintelligent juvenile waivers of the privilege against self-incrimination. By excluding an adult as incompetent if he has a close relationship, as defined in negligent infliction of emotional distress tort cases, with any of the victims of the crime of which the juvenile is accused, or with any of the other suspects in the crime, courts and the police can help prevent the admission of unconstitutionally obtained confessions and can protect a juvenile's rights. 